\title{
DANCE PERSPECTIVES ON DRUM LANGUAGE: A YORUBA EXAMPLE
}

\author{
Natasa Chanta-Martin \\ Choreomundus Master Programme - International Master in Dance Knowledge, Practice and Heritage \\ Kalama 10, 15343, Aghia Paraskevi, Athens, Greece \\ E-mail: natasa.chanta.martin@gmail.com
}

\begin{abstract}
Among the Yoruba people of southwest Nigeria, dancers have the ability to relate not only to music and rhythm, but also to the Yoruba tonal language. This is due to the fact that instruments being played during a dance event, once they are manipulated by the drummer, can follow the Yoruba language's tonality. Therefore, the so-called talking drums have the ability to articulate proverbs, poems, stories. The dancers' representations or interpretations of what the drums are saying create different artistic and cognitive dimensions during the dancing. When does a dancer follow only the rhythms of the drums and when does he or she have meaning in his/her gestures? What happens when the meanings derive from proverbial language? And moreover, what happens with the newest Yoruba dance generation which is said to have neglected their indigenous language for English? Going beyond choreomusical relationships, improvising, mimicking, interpreting and verbalising the content of the tonal percussions are some dimensions of Yoruba dance, which derive from exploring the personal dance experiences of a community of thought in Yorubaland.
\end{abstract}

Keywords: Nigerian Yoruba dance, drum language, speech surrogates, talking drums

\section{INTRODUCTION}

The notion of drum language finds its significance in the beginning and the middle of the twentieth century. Ethnographic material and anthropological writings discuss situations where a "drum serves as the sound-making apparatus". In this sense, specific percussive instruments are manipulated by drummers in a way, through which they represent or imitate the tonality of the spoken language. Readings on drum and whistle languages draw examples which derive, mainly, from African countries, such as Congo, Nigeria, and Ghana. ${ }^{2}$ In French terminology, langage tambourine and langage sifflé are

${ }^{1}$ JeWETT 1977: 25.

${ }^{2}$ Ames - Gregersen - Neugebauer 1971; Carrington 1944; Clarke 1934; Locke - Agbeli 1980, 1981; Rattray 1923a, 1923b; Sebeok - UMiek-SEbeok 1976; Stern 1957. 
most commonly used to express similar meaning of a spoken language, which is verbalized by percussive instruments, and they have been academically investigated during the same period of time. ${ }^{3}$ Another term widely used from the previous century has been the so-called talking drums, the category of percussive instruments, which have the ability to imitate respectively their community's spoken language. ${ }^{4}$

When trying to approach drum language from a dance viewpoint, two major issues arise in relation to bibliographical sources and academic readings. Firstly, although the existence of a rich amount of sources is extremely desirable for an academic interested in African drum language and talking drums, the chronological period of their production has almost transformed them into ethnographic texts, in which the weight has been shifted towards their historical significance, rather than their anthropological relativity to present situations. In the eyes of a young researcher, who is seeking theoretical frameworks prior to or during anthropological fieldwork, the exploration of bibliographical sources, which have been majorly created even decades before her birth, often supplement moments of befuddlement, which preexist due to ignorance and inexperience of the unknown field itself. Simultaneously, they create further motivation for an elaboration and continuation of research.

Secondly, another issue related to the aforementioned sources is connected to their content. An important amount of the above ethnographic material is examined from an ethnomusicological approach, or a combination of a linguistic and musical point of view. The short references, or descriptions regarding the dancing in relation to "the integral function of drum language"s or talking drums, give the impression that they may occur from the often observed, inseparable relationship between music and dance in an African context. Therefore, an emphasis on elaborated examination of drum language from the dance researcher's perspective becomes almost a necessity. Taking as example situations of dance in a Nigerian Yoruba context, some introductory points will be mentioned in this paper about the Yoruba language and Yoruba talking drums, before proceeding to the drum language and the dance itself.

\section{THE YORUBA CONTEXT}

The Yoruba language is part of the large Niger-Congo language family and it constitutes indispensable means of verbal and non-verbal communication and cultural expression. Along with Igala, another Nigerian language, it belongs to the Yoruboid subgroup of Eastern Central Niger-Congo (CNC) language group. ${ }^{6}$ Yoruba, like many other African and Asian ethnic ${ }^{7}$ languages, is characterised by multiple tones and monosyllabic words. That means, a specific word has a different meaning depending on how it is intonated.

\footnotetext{
${ }^{3}$ Bariaux - Demolin 1995; Dugast 1955; Labouret 1923; Mvula Ngembe 1980; Rouget 1964; Titinga 1988; VERBEKEN 1953; ZEMP 1997.

${ }^{4}$ Armstrong 1954; Beier 1954; Euba 1990; Ong 1977; Price 1973.

${ }^{5}$ Locke - AgBeli 1981: 25.

${ }^{6}$ BennetT - STERK 1977.

${ }^{7}$ Ethnic is meant here as a language belonging to an ethnic group of a country.
} 
For example:

$\begin{array}{ll}\text { igbá } & \text { calabash } \\ \text { igbà } & \text { time } \\ \text { igba } & 200 \\ \text { igbàa } & \text { type of rope } \\ \text { igbáa } & \text { type of vegetable }\end{array}$

An important factor related to drum language is the particular tonal structure of Yoruba language. Yoruba is a tonal language, which consists of three tones and two glides, and, therefore, the meaning of a word can crucially change even if only one of its syllables is intonated differently. ${ }^{9}$

Descriptive characteristics of this language find their significance in a specific group of pressure drums of Yoruba culture. The Dùndún is a drum ensemble, which consists of six differently sized drums (Iya ilu, Gudugudu, Keri keri, Isaju, Kannango, Gangan ${ }^{10}$ ). The latter are constructed by different kinds of membranes, which give a range of tone to the instruments. Most of the Dùndún drums include a double membrane, they are hourglass-shaped and they have tension thongs attached at every end. The way these instruments are played is what gives them a wider tonal range. The main Dùndún drums, for example, are held by a strap over the drummer's shoulder and by squeezing and releasing the tension thongs the pitch of the sound varies significantly, when the drummer strikes the head of the drum with a curved wooden stick called kòngó.

The tonal structure of the music is based on the tonal structure of the language. 'The accent and the speech tones govern the music to a great extent - exact imitation of the tones - almost exactly as it would be sung - the drums replace the human voice'. ${ }^{11}$ Inevitably, that requires the drummer to have an adequate knowledge of the Yoruba oral literature making him at the same time an excellent linguist apart from a musician. This supplements the fact that these percussive instruments do not only interpret a specific rhythm pattern, but they also have the ability to "talk" to the audience or to other performers involved. A well-known term for tonal percussive instruments is "talking drums". As stated by Bankole:

The intimate relationship between spoken Yoruba, which is a tonal language, and music is the essence of Yoruba music. Because of this relationship, whereby single drums and combinations of drums can be made to imitate Yoruba intonation, virtually anything spoken can be drummed. All Yoruba music communicates meaning to the listeners. Every melody, even if not consciously verbalized by the listener, was originally conceived as spoken Yoruba. ${ }^{12}$

\footnotetext{
${ }^{8}$ SCHLEICHER 2007: 14.

${ }^{9}$ Pulleyblank 1988; Wedekind 1985.

${ }^{10}$ The gángan drum can also be called àpàlà or àdàmò.

${ }^{11}$ Vidal 1969.

${ }^{12}$ Bankole - Bush - Samaan - Anyidoho - Alafuele - Ebong 1975: 52.
} 


\section{THE YORUBA EXAMPLE}

The main talking drums, in relation to which the dance has been researched, are the main solo drums, called Iya ilu, which can be translated as the "mother drum", and a quite popular smaller participant, known as "the talking drum" in English, though it is called Gangan in Yoruba. During a Yoruba performance, the phrases being "said" by these drums are usually proverbs, maxims, calls or praise poetry and the latter's content can be heard and understood by the audience, or other participants, including the dancers. A Yoruba choreographer, Peter Badejo once mentioned: "A dancer has to be a listener, and a drummer has to be a mover. You cannot dance unless you know the music, drumming and language". ${ }^{13}$

Indeed, an interlocutor during research in Yorubaland in 2013 declared:

I am not listening to the lead drummer. But the lead drummer will not be far from my head. So, when he will give me the cue, I will know. Your head has to understand what each drum is playing. ${ }^{14}$

The cognitive aspect of dancing to talking drums seems like an essential factor when approaching drum language from a dance perspective. In Yoruba dance, the individual exposes his/her knowledge on rhythm, movement, and language. The dancer has the opportunity of making choices on what he/she wants to focus on, and he/she can distinctively present that while dancing. However, Yoruba dance has conventions of its own, which relate to the improvisational, more "abstract" part ${ }^{15}$, as well as to the "narrative" and proverbial part of the dance. For instance, during the improvisational part, the dancer is committed to specific rhythmical rules and short rhythm phrases, which commence, end, or "interrupt" the rhythmic flow. Moreover, in the narrative part, the content of the text represented by the talking drums can be of different dimensions. This means that the proverbs, poems, or stories played can range between more distinct descriptions, such as: "I can use my arms to dance, I can use my legs to dance, I can use my whole body to dance", to less direct images like: "My head should not trouble me, God do not trouble me, I am thankful", or even phrases that entail further meaning, such as: "How big a leaf is, is not necessarily how useful it is".

The above examples can be danced in many ways depending on choice and individual creativity of the dancer, but they often operate within specific boundaries. For example, a dancer would most likely not move his feet while interpreting "I can use my arms to dance". However, the way to move the arms, in order to relate to the phrase's meaning, is free for the dancer to decide.

In regards to the second example, the collaborators of the field were performing it in a more mimetic way, by touching their head and kneeling down in the form of a prayer. Again, the way of mimicking this proverb varied from dancer to dancer. Lastly, the proverb coloured by, what the locals call a "deeper" meaning, was usually performed by marking the particular rhythm the phrase created, without attaching meaning to their

\footnotetext{
${ }^{13}$ Informal interview, Nigeria, 2013.

${ }^{14}$ Formal interview, Nigeria, 2013.

${ }^{15}$ The interlocutor names this part of Yoruba dancing "free dance".
} 
gestures. Often these proverbial phrases were verbalised from the dancers as they kept dancing to the basic rhythm of the rest of the drums, or they were stepping with their feet in synchronisation to the rhythmical continuation of the drum language itself.

In situations where the dancer does not comprehend the proverbs or stories played, it is not frowned upon to continue dancing to the supporting rhythm patterns. However, depending on the content of the "narrative" part of Yoruba drum language, and whether the dancer realises and chooses to react to it, it seems like there is quite a range for interpretation.

\section{CONCLUSION}

In an attempt to summarise the various forms of dance interpretation expressed by Yoruba interlocutors during fieldwork, it has been witnessed that during Yoruba dances the performers could interact with the talking drums by manifesting themselves through the following dance dimensions:

- Improvising with movements, which relate only to the rhythm of the drum ensemble

- Moving rhythmically to a phrase played by a talking drum ("rhythm" of drum language)

- Mimicking the content of the proverb/story/poem (in a more theatrical way)

- Interpreting the content of the phrases

- Verbalising what the talking drums are saying

The above dance dimensions, which occur during Yoruba dance, do not stand individually. They, rather, interrelate to each other by happening during the same dance piece (even simultaneously at times), where Yoruba drum language is predominant. An exploration of the experiences of the "active protagonists of the dance"16 can better reflect the "relationships as they are lived"17 from the perspective of dance interlocutors and their relation to drum language witnessed during fieldwork. Therefore, it can be pro tempore concluded that Yoruba dancing changes depending on the situated levels of meaning, which the drum language encompasses.

\section{LITERATURE}

AdeIYi, Adebayo

2013: Interviewed by Natasa Chanta-Martin in Ile-Ife, Nigeria.

Ames, David W. - Gregersen, Edgar A. - Neugebauer, Thomas

1971: Taaken Sàmàarii: A Drum Language of Hausa Youth. Africa 41, 12-31.

Armstrong, Robert G.

1954: Talking Drums in the Benue-Cross River Region of Nigeria. Phylon 15(4), 355-363.

\footnotetext{
${ }^{16}$ Martin 1967: 23.

${ }^{17}$ JACKSON 1996: 26.
} 
BADEJO, Peter

2013: Interviewed by Natasa Chanta-Martin in Ile-Ife, Nigeria.

Bankole, Ayo - Bush, Kudith - Samaan, Sadek H. - Anyidoho, Kofi - Alafuele, Mbuyi-Kalal - Ebong, Inih Akpan

1975: The Yoruba Master Drummer. African Arts 8(2), 48.

Bariaux, Daniel - Demolin, Didier

1995: Naissance de la voix d'un tambour à fente chez les Mangbetu: du geste de l'artisan à celui du musicien et du danseur. Cahiers de musiques traditionnelles 105-114.

BEIER, Ulli

1954: The Talking Drums of the Yoruba. African Music 1(1), 29-31.

Bennett, Patrick R. - Sterk, Jan P.

1977: South Central Niger-Congo: A Reclassification. Studies in African Linguistics 8(3), 241-273.

CARrington, John F.

1944: The Drum Language of the Lokele Tribe. African Studies 3, 75-88.

Clarke, Robert T.

1934: The Drum Language of the Tumba People. American Journal of Sociology 40(1), 34-48.

Dugast, Idelette

1955: Le langage tambourine ou siffle chez les Banen. Excerpted from Travaux et mémoires de l'Institut d'Ethnologie 50(App. I), 567-602.

EuBA, Akin

1990: Yoruba Drumming: The Dundun Tradition. Bayreuth: Bayreuth African Studies Series.

JACKSON, Michael (Ed.)

1996: Things as They Are: New Directions in Phenomenological Anthropology. Bloomington: Indiana University Press.

JEwetT, Susan E.

1977: Drum Languages and Their Messages. Master thesis. Available at http://ir.library.oregonstate.edu/ xmlui/handle/1957/43189 (accessed: 22/12/13)

LABOURET, Henry

1923: Langage tambouriné et sifflé. In: Sebeok, Thomas A. - Umiker-Sebeok, Donna J. (eds.): Speech Surrogates. The Hague: Walter de Gruyter.

Locke, David - Agbeli, Godwin

1980: A Study of the Drum Language in Adozogbo. African Music Grahamstown 6, 32-51.

1981: Drum Language in Adzogbo. The Black Perspective in Music 9, 25-50.

Martin, György

1967: Dance Types in Ethiopia. Journal of the International Folk Music Council 19, 23-27.

Mvula NGembe, Shungu

1980: Le langage tambourine chez les tetela (Zaire). (Doctoral dissertation)

ONG, Walter J.

1977: African Talking Drums and Oral Noetics. New Literary History 8, 411-429.

Price, Christine

1973: Talking Drums of Africa. New York: Scribner.

Pulleyblank, Douglas

1988: Vocalic Underspecification in Yoruba. Linguistic Inquiry 19(2), 233-270.

RATTRAY, Robert S.

1923a: The Drum Language of West Africa: Part I. Journal of the Royal African Society 22(87), $226-236$.

1923b: The Drum Language of West Africa: Part II. Journal of the Royal African Society 22(88), 302-316.

Rouget, Gilbert

1964: Tons de la langue, en gun (Dahomey), et tons du tambour. Revue de musicologie 50, 3-29.

SCHLEICHer, Antonia Y. F.

2007: Colloquial Yoruba: The Complete Course for Beginners. New York: Routledge.

Sebeok, Thomas A. - Umiker-Sebeok, Donna J.

1976: Speech Surrogates. The Hague: Walter de Gruyter.

STERn, Theodore 
1957: Drum and Whistle "Languages": An Analysis of Speech Surrogates. American Anthropologist 59, 487-506.

Titinga, Pacéré

1988: Parole et poésie du tam-tam: Introduction et compréhension du langage tambouriné Vol. 4. Ouagadougou: TF Pacéré.

Verbeken, Auguste

1953: Le language tambouriné des congolais. The African Music Society Newsletter 1(6), 28 -41.

VIDAL, Tunji

1969: Oriki in Traditional Yoruba Music. African Arts 3(1), 56-59.

WedEKIND, Klaus

1985: Thoughts When Drawing a Map of Tone Languages. Afrikanistische Arbeitspapiere 1, 105-124.

ZEMP, Hugo

1997: Composer et interpréter des rythmes. Musique et langage tambouriné chez les 'Aré'aré. [Composing and Performing Rhythms: Drum Music and Drum Language among the 'Are'are] Cahiers de musiques traditionnelles 10, 191-235. 